\title{
Hydrogen and Methane Production Under Conditions of Anaerobic Digestion of Key-Lime and Cabbage Wastes
}

\author{
Gaweł Sołowski*, Izabela Konkol, Bartosz Hrycak, Dariusz Czylkowski \\ Institute of Fluid Machinery of Polish Academy of Science, Gdansk, Poland \\ *Email: gsolowski@imp.gda.pl
}

Submission: May 27, 2018 ; Acceptance: July 2, 2019

\begin{abstract}
In this article, the results of key lime fruit (Citrus aurantifolia) wastes and cabbage (Brassica L.) wastes anaerobic digestion are presented. Anaerobic digestion of the wastes was performed in batch process, neutral pH (key-lime 7.47 and cabbage 7.67) and substrate concentration of Volatile Suspended Solids (VSS) $10 \mathrm{gVSS} / \mathrm{L}$. One of the aims of this research was to check the availability of these substrates to be the source of methane and hydrogen. Key lime wastes produced 32 times more methane than raw cabbage. However, hydrogen production from cabbage was 149 times higher than key lime. The percentage of methane production in cabbage was up to $81 \%$ and in key lime was up to $75 \%$. This research showed from the substrates comparison that efficient hydrogen production is less dependent on low $\mathrm{pKa}, \mathrm{pH}$ than on total solids of the substrates.
\end{abstract}

Keywords: Anaerobic digestion; dark fermentation; hydrogen; methane; key-lime

\section{INTRODUCTION}

Hydrogen and methane are prime materials for many reactions, and possible green fuel for replacement of conventional source of energy (Kurtz et al., 2019). Demanding on them is increasing thus enhance variety of potential pathways of obtaining is necessary (Parra et al., 2019). The problem hydrogen production is also its storage that inhibits development of biohydrogen processes (Lamb et al., 2019). Due to exploitation of fossil fuels there is necessary to look for new routes and materials to fulfil the demand for these compounds (Sołowski, 2018). The potential methods to enhance variety of pathways and fulfil temand for the compounds are anaerobic digestion including dark fermentation. Anaerobic digestion transforms fats, aminoacids, and sugars into hydrogen, low organic acids and carbon dioxide and then for methane. Dark fermentation is a type of anaerobic digestion process where simple sugar (glucose or fructose) or glycerol is converted into hydrogen, carbon dioxide and low organic acids, and processed is stopped on this point (Chojnacka et al., 2015). Biogas follows dark fermentation in typical anaerobic digestion process, must be inhibited (Sharma, 2019). There is some disagreement if in dark fermentation process could or could not sludge be pretreated (stressed) and methane production can occur (Detman et al., 2018; Hawkes et al., 2002). In dark fermentation process, bacterial sludge (inoculum) is usually pretreated by stressing using: heat (preheating or freezing), ultrasound or microwaves, centrifuging, chemicals, or change of pH (Muñoz-Páez et al., 2018) but works Lakaniemi et al. (2011) shows that untreated raw sludge can be also successful also with hydrogen production. One of the known problems of the dark fermentation is an selection of proper material from waste material to produce hydrogen (Sołowski, 2018) . There are many attempts to of batch or reactor type to solve problem but it does not bring solution to scale up process of dark fermentation, the process is to unstable and hydrogen production breaks after some time (Taheri et al., 2018). Other trouble is still low conversion to hydrogen(Michalopoulos et al., 2019). The biomethane production anaerobic digestion is much better known, industrially used, but there is still need to improve production to be suitable designing to the 
region (Merzari, et al., 2019). The anaerobic digestion and dark fermentation is usually for low heating cost kept or investigate in mesophilic range $33^{\circ} \mathrm{C}-40^{\circ} \mathrm{C}$ but recent updates of possible precious by-products like lactic acid causes that the thermophilic conditions 55 ${ }^{\circ} \mathrm{C}-60{ }^{\circ} \mathrm{C}$ are gaining more interest (Pradhan et al., 2019). Hydrogen production by dark fermentation optimal pH seem to be 5.0 to 6.0 while for methane production seemed to be 7 to 9 (Muñoz-Páez et al., 2018). Therefore relevant objective seemed checking availability for hydrogen and methane production of substrates of low pH (PETÄJÄ et al., 2008). After the promising results obtained for $10 \mathrm{~g}$ VSS /L of sour cabbage (Sołowski et al., 2018), the research was continued for raw cabbage (Brassica $L$ ) and lime fruit (Citrus aurantifolia) for the same VSS $10 \mathrm{~g}$ VSS /L. The all substrate possess high sugar content $51 \%$ (key lime (Liu et al., 2012) $81 \%$ of cellulose in raw cabbage (Jaiswal et al., 2012). Organic acid present in two fruit citric acid (key lime) and lactic acid seemed to be due to low pH good candidate as substrate for anaerobic digestion and hydrogen production. The sour cabbage, cabbage (Brassica L), that is preserved (pickled) by lactic acid fermentation - popular in Middle - Europe). On the other can conditions, where dark fermentation can or cannot occur can be useful in medicine because case of undesired dark fermentation in our body can be considered gangrene(Chi et al., 1995).

\section{MATERIALS AND METHODS}

The fermentation process of waste raw cabbage and key lime was performed in glass reactors (jars) of volume $2 \mathrm{dm}^{3}$. The fermentation was kept in mesophilic condition $38^{\circ} \mathrm{C}$. As inoculum, sludge from a biogas plant in Lubań (Pomerania Region) without any pretreatment (raw inoculum) was used according to Lakaniemi et al (Lakaniemi et al., 2011)biodegradability, abundance, availability and cost determine the amenability of carbonaceous substrate for fermentative hydrogen and methane production systems. The aim of the present work was to determine suitability of lignocellulosic material, reed canary grass (RCG. Inoculum sludge $\mathrm{pH}$ was 8.24 , total solids (TS) $1.09 \%$ and Volatile suspended solids (VSS) $37.44 \%$. The waste key-lime and cabbage. Outdated and not available as food, were taken from RENK Pomeranian Agri-food Wholesale Center S.A. The raw cabbage and key lime fruit was prepared by milling and mixing it. $10 \mathrm{~g} / \mathrm{L}$ volatile suspended solids (VSS) were applied to each batch of cabbage and waste lime fruit. Anaerobic conditions were gained by flushing with nitrogen of reactors. After adding cabbage to inoculum, the jar content $\mathrm{pH}$ was 7.47 in cabbage and after adding key-lime 7.67. The $\mathrm{pH}$ of fermenting, monitored one time per day and the change of $\mathrm{pH}$ was not observed during fermentation time. The characteristics of inoculum and substrates are shown in Table 1.

In case of cabbage batch the biogas was formed among 17 days and in case of key lime 25 days. The biogas produced was measured using the Owen method and analyzed using TCD Gas Chromatography (GC). As a gas carrier was used argon. TCD Chromatograph used silico packed single column Restek ${ }^{\circledR}$ of characteristics $2 \mathrm{~m} / 2 \mathrm{~mm}$ ID $1 / 8^{\prime \prime}$ OD Silica. GC flow rate used for determination of hydrogen, methane nitrogen, oxygen, carbon dioxide and carbon monoxide was $0.6 \mathrm{~mL} / \mathrm{h}$.

\section{RESULTS AND DISCUSSION}

GC analysis allowed the determination of methane, hydrogen, carbon dioxide, carbon monoxide, oxygen and nitrogen concentration. The biogas obtained from the substrates besides methane and hydrogen contained carbon dioxide and neglible amount of carbon monoxide and ethylene. The biogas volumes obtained from substrates are: key-lime wastes during $600 \mathrm{~h}$ ( 25 days) was $4.31 \mathrm{dm}^{3}$ and raw cabbage during $385 \mathrm{~h}$ (16 days) $0.018 \mathrm{dm}^{3}$. The results from these substrates are lower than from sour cabbage $10 \mathrm{~g}$ VSS /L during $400 \mathrm{~h}$ (16.7 days) there was obtained $9.59 \mathrm{dm}^{3}$ of biogas. The results of biogas production was compared in Figure 1. In Figures 2 and 3 are shown results for methane and hydrogen production with comparison of data from earlier researches (Sołowski et al., 2019; Sołowski et

Table 1. Characteristics of inoculum, sour cabbage, raw cabbage and key lime

\begin{tabular}{lccc}
\hline Material & $\mathrm{pH}$ & $\mathrm{TS}$ & VSS \\
\hline Inoculum & 8.24 & $1.09 \% \pm 0.028 \%$ & $37.44 \% \mathrm{TS} \pm 1.03 \%$ \\
Sour Cabbage & 4.61 & $6.99 \% \pm 0.022 \%$ & $89 \% \mathrm{TS} \pm 1.2 \%$ \\
Raw Cabbage & 6.27 & $1.8 \% \pm 0.013 \%$ & $92 \% \mathrm{TS} \pm 1.05 \%$ \\
\hline Key Lime & 3.41 & $5.61 \% \pm 0.03 \%$ & $94.39 \% \mathrm{TS} \pm 0.82 \%$ \\
\hline
\end{tabular}




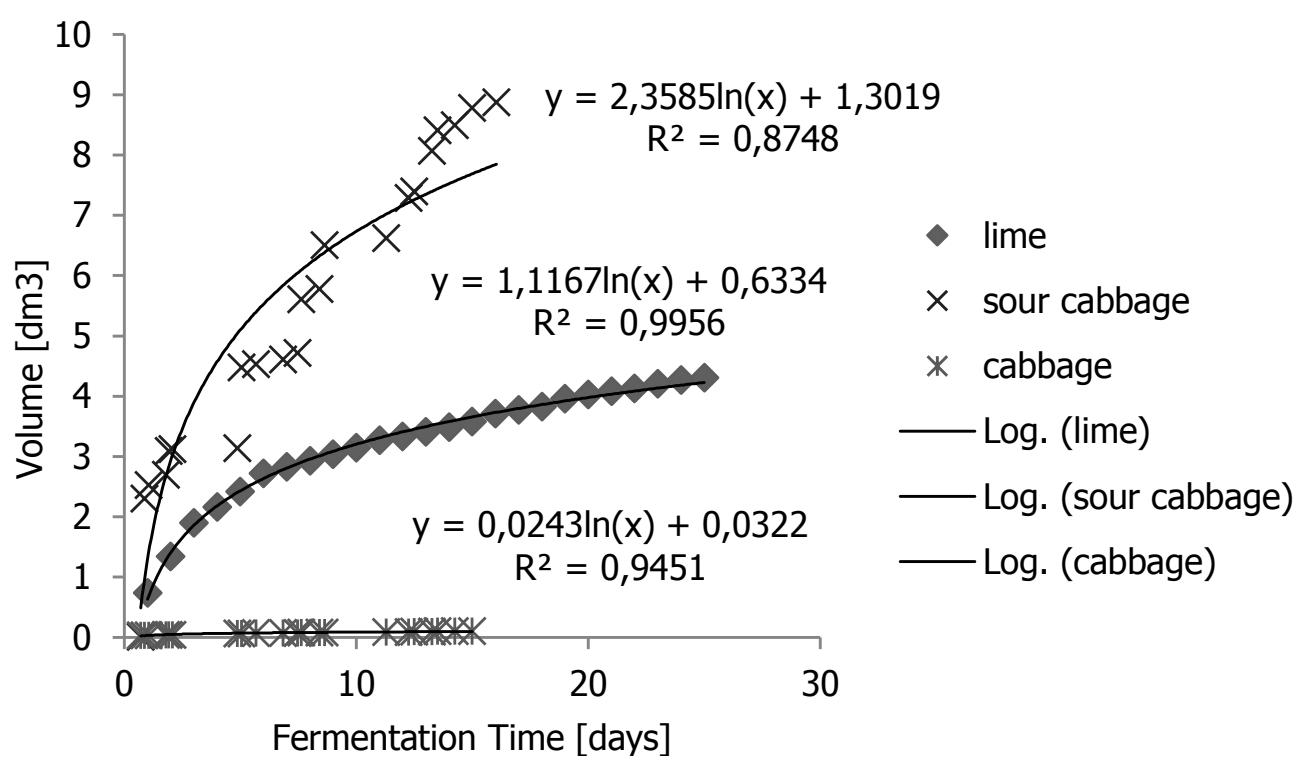

Figure 1. Time evolution of cumulative biogas production of key lime(blue rhombi), sour cabbage (violet crosses), cabbage (blue-light asterisk)

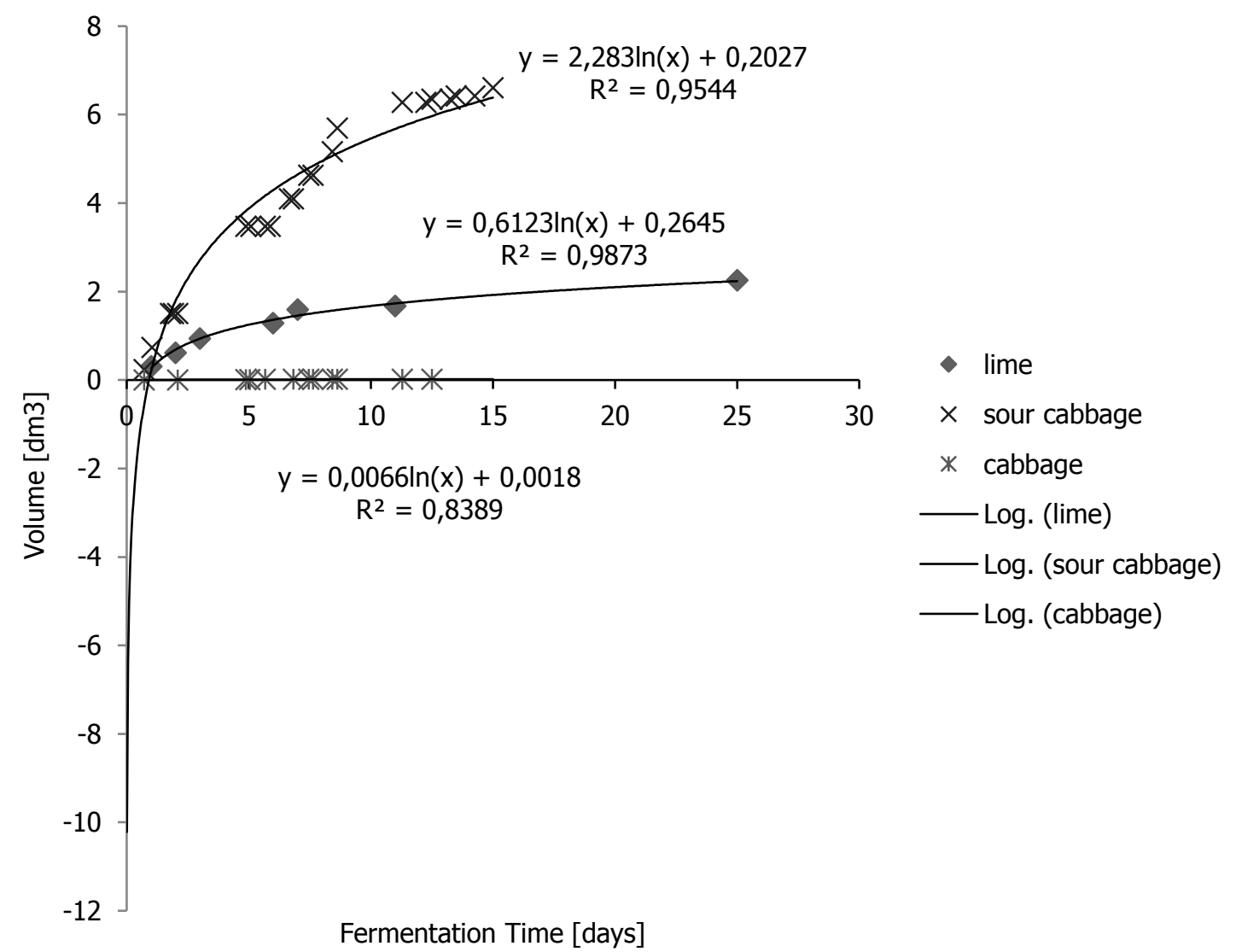

Figure 2. Time evolution of cumulative methane production conditions of key lime (blue rhombi), sour cabbage (violet crosses), cabbage (blue-light asterisk) for $10 \mathrm{~g} \mathrm{VSS} / \mathrm{L}$ 
Table 2. Comparison of methane, hydrogen yield from different substrates

\begin{tabular}{|c|c|c|c|c|c|c|c|}
\hline Substrate & inoculum & $\begin{array}{l}\text { Conditions, } \mathrm{T}- \\
\text { temperature, } \mathrm{pH}\end{array}$ & $\begin{array}{l}\text { Methane } \\
\text { Yield } \\
\mathrm{dm}^{3} / \mathrm{g} \text { VSS }\end{array}$ & $\begin{array}{l}\text { Methane } \\
\text { Peak day } \\
\mathrm{dm}^{3} / \text { day }\end{array}$ & $\begin{array}{l}\text { Hydrogen } \\
\text { Yield } \mathrm{dm}^{3} / \mathrm{g} \\
\text { VSS }\end{array}$ & $\begin{array}{l}\text { Hydrogen Peak } \\
\text { day } \mathrm{dm}^{3} / \text { day }\end{array}$ & References \\
\hline $\begin{array}{l}\text { Sour cabbage } 10 \mathrm{~g} \\
\text { VSS /L }\end{array}$ & $\begin{array}{l}\text { Raw } \\
\text { agriculture } \\
\text { digestate }\end{array}$ & $\begin{array}{l}\text { Anaerobic } \mathrm{T}=38 \\
\mathrm{pH} 7.8\end{array}$ & 0.66 & $\begin{array}{l}1.975^{\text {th }} \\
\text { day }\end{array}$ & 0.0079 & $0.058^{\text {th }}$ day & $\begin{array}{l}\text { (Sołowski, } \\
\text { Hrycak, } \\
\text { Czylkowski, } \\
\text { Pastuszak, et } \\
\text { al., 2018) }\end{array}$ \\
\hline $\begin{array}{l}\text { Sour cabbage } 10 \mathrm{~g} \\
\text { VSS /L }\end{array}$ & $\begin{array}{l}\text { Raw } \\
\text { agriculture } \\
\text { digestate }\end{array}$ & 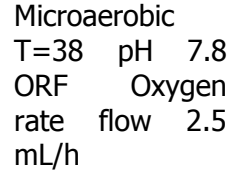 & 0.28 & $\begin{array}{l}0.795^{\text {th }} \\
\text { day }\end{array}$ & 0.049 & $0.086^{\text {th }}$ day & $\begin{array}{l}\text { (Sołowski, } \\
\text { Hrycak, } \\
\text { Czylkowski, } \\
\text { Pastuszak, et } \\
\text { al., 2018) }\end{array}$ \\
\hline $\begin{array}{l}\text { Sour cabbage } 5 \mathrm{~g} \\
\text { VSS /L }\end{array}$ & $\begin{array}{l}\text { Raw } \\
\text { agriculture } \\
\text { digestate }\end{array}$ & $\begin{array}{l}\text { Anaerobic } \mathrm{T}=38 \\
\mathrm{pH} 7.8\end{array}$ & 0.17 & $\begin{array}{l}0.363^{\text {th }} \\
\text { day }\end{array}$ & 0.00043 & $0.0171^{\text {st }}$ day & $\begin{array}{l}\text { (Sołowski et } \\
\text { al., 2019) }\end{array}$ \\
\hline $\begin{array}{l}\text { Sour cabbage } 5 \mathrm{~g} \\
\text { VSS } / \mathrm{L}\end{array}$ & $\begin{array}{l}\text { Raw } \\
\text { agriculture } \\
\text { digestate }\end{array}$ & 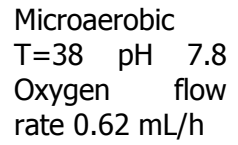 & 0.195 & $\begin{array}{l}0.465^{\text {th }} \\
\text { day }\end{array}$ & 0.0013 & $0.00321^{\text {st }}$ day & $\begin{array}{l}\text { (Sołowski et } \\
\text { al., 2019) }\end{array}$ \\
\hline Key lime $10 \mathrm{~g}$ VSS /L & $\begin{array}{l}\text { Raw } \\
\text { agriculture } \\
\text { digestate }\end{array}$ & $\begin{array}{l}\text { Anaerobic } T=38 \\
\mathrm{pH} 7.67\end{array}$ & 0.256 & $\begin{array}{l}0.6425^{\text {th }} \\
\text { day }\end{array}$ & 0.0000016 & $\begin{array}{l}0.0000055 \\
1^{\text {st }} \text { day }\end{array}$ & This study \\
\hline $\begin{array}{l}\text { Raw Cabbage } 10 \mathrm{~g} \\
\text { VSS /L }\end{array}$ & $\begin{array}{l}\text { Raw } \\
\text { agriculture } \\
\text { digestate }\end{array}$ & $\begin{array}{l}\text { Anaerobic } T=38 \\
\text { pH } 7.67\end{array}$ & 0.018 & $\begin{array}{l}0.124^{\text {th }} \\
\text { day }\end{array}$ & 0.00047 & $0.001414^{\text {th }}$ day & This study \\
\hline $\begin{array}{l}\text { Food wastes with } \\
\text { olive husks } 15 \mathrm{~g} \\
\text { VSS/L }\end{array}$ & $\begin{array}{l}\text { Raw } \\
\text { sewage } \\
\text { from } \\
\text { municipal } \\
\text { waste plant }\end{array}$ & $\begin{array}{l}\text { Anaerobic } \mathrm{T}=37 \\
\mathrm{pH} 7.0\end{array}$ & 0.446 & - & 0.005 & - & $\begin{array}{l}\text { (Pagliaccia et } \\
\text { al., 2016) }\end{array}$ \\
\hline $\begin{array}{l}\text { Algal bloom biomass } \\
10 \mathrm{~g} / \mathrm{L}\end{array}$ & $\begin{array}{l}\text { Heat } \\
\text { shocked } \\
\text { biogas } \\
\text { digestate } \\
\text { mixed with } \\
\text { rumen }\end{array}$ & $\begin{array}{l}\text { Anaerobic } \quad T=37 \\
\mathrm{pH} 6.0\end{array}$ & 0.271 & - & 0.018 & - & $\begin{array}{l}\text { (Cheng et al., } \\
\text { 2019) }\end{array}$ \\
\hline $\begin{array}{l}\text { Food waste residue } 7 \\
\text { g/L }\end{array}$ & - & $\begin{array}{l}\text { Anaerobic } \quad T=37 \\
\text { pH } 7.0\end{array}$ & 0.444 & - & 0.062 & - & $\begin{array}{l}\text { (Michalopoulos } \\
\text { et al., 2019) }\end{array}$ \\
\hline $\begin{array}{l}\text { Waste Activated } \\
\text { sludge primary } \\
\text { sludge } 10 \mathrm{~g} \text { VSS/L }\end{array}$ & $\begin{array}{l}\text { Raw } \\
\text { sewage } \\
\text { sluge }\end{array}$ & $\begin{array}{l}\text { Anaerobic } \quad \mathrm{pH} \\
6.9 \mathrm{~T}=37\end{array}$ & 0.212 & - & - & - & $\begin{array}{l}\text { (Grosser \& } \\
\text { Neczaj, 2016) }\end{array}$ \\
\hline $\begin{array}{l}\text { Reed canary grass } 5 \\
\text { g VSS/L }\end{array}$ & $\begin{array}{l}\text { Digested } \\
\text { (municipal } \\
\text { activated } \\
\text { sludge) }\end{array}$ & $\begin{array}{l}\text { Anaerobic } \\
\text { pH } 4.6 \mathrm{~T}=38\end{array}$ & & & 0.036 & & $\begin{array}{l}\text { (Lakaniemi et } \\
\text { al., 2011) }\end{array}$ \\
\hline $\begin{array}{l}\text { Depackaging } \\
\text { wastes/none } 4 \\
\text { gVSS/L }\end{array}$ & $\begin{array}{l}\text { Untreated } \\
\text { sewage } \\
\text { sludge }\end{array}$ & $\begin{array}{l}\text { Anaerobic } p H \\
7.0 \mathrm{~T}=37^{\circ} \mathrm{C}\end{array}$ & - & - & 0.0014 & - & $\begin{array}{l}\text { (Noblecourt, } \\
\text { Christophe, } \\
\text { Larroche, \& } \\
\text { Fontanille, } \\
\text { 2018) }\end{array}$ \\
\hline
\end{tabular}

al., 2018). For better observation off changes of growth of biogas from chosen substrates, trend lines with deviations $\left(\mathrm{R}^{2}\right)$ are added.

It can be discerned that key-lime produced longer biogas (in days) but less volumes. Key lime wastes is digested longer and one portion of key-lime waste can produce biogas for more days than the other substrates.
The volume of methane and hydrogen produced during anaerobic conditions are from three substrates:

- $\quad$ key lime $2.56 \mathrm{dm}^{3} \pm 0.01 \mathrm{dm}^{3}$ of methane and $0.000015 \mathrm{dm}^{3} \pm 0.0000001 \mathrm{dm}^{3}$ of hydrogen in 600 hours

- cabbage $0.18 \mathrm{dm}^{3} \pm 0.0001 \mathrm{dm}^{3}$ of methane and $0.0047 \mathrm{dm}^{3} \pm 0.00001 \mathrm{dm}^{3}$ of hydrogen in 385 hours 
- $\quad$ sour cabbage $6.60 \mathrm{dm}^{3} \pm 0.001 \mathrm{dm}^{3}$ of methane and $0.079 \mathrm{dm}^{3} \pm 0.0001 \mathrm{dm}^{3}$ of hydrogen in 400 hours

It can be observed that key lime fermentation is longer of 9 days. However during this additional 9 days the production produce $25 \%$ of overall production of methane and $13.9 \%$ of biogas and still less than methane production from 16.6 days from sour cabbage. The methane and hydrogen potential of cabbage springs significantly after anaerobic preservation with lactic acid.

Average concentration of methane in biogas in key lime is $75 \%$, in raw cabbage $81 \%$ while in sour cabbage $86 \%$ (Sołowski et al., 2019) that is more than in case of food residues $67-70 \%$ (Michalopoulos et al., 2019)Athens, 2017. Methane production of key lime is on the level of anaerobic digestion of algal bloom biomass and slightly less that mixed food wastes (Pagliaccia et al., 2016)to assess the influence of composition and $\mathrm{pH}$ on hydrogen and methane production. Process intensification with thermal pretreatment to further enhance the biological conversion of substrate constituents was investigated, too. Best performance in terms of $\mathrm{H} 2$ production (up to $87 \mathrm{NL} / \mathrm{kg}$ VSfed. Sour cabbage produce more methane than in case food wastes of Braguglia et al. (2018). The data of research are compared with results for fermentation of sour cabbage under the same load 10 and $5 \mathrm{~g}$ VSS /L (Sołowski et al., 2018) - see Figure 2 and Table 2.

The table 2 shows that results of measuring of both methane and hydrogen production are very rarely published as considered also Braguglia et al (Braguglia et al., 2018). Therefore, the interplay of methane and hydrogen production with compare of other articles can give hints for efficient separation of both processes. In Table 2 were compared hydrogen and methane yields and peak day of the production. The peak days of hydrogen production in key-lime waste of $10 \mathrm{gVSS} / \mathrm{L}$ and $5 \mathrm{gVSS} / \mathrm{L}$ of sour cabbage occured in first day like usually in case of untreated dark fermentation (Michalopoulos et al., 2019)Athens, 2017. In case of raw cabbage $10 \mathrm{gVSS} /$ day hydrogen peak day occurred 3 day after methane peak day in the end of the process. In case of sour cabbage $10 \mathrm{gVSS} / \mathrm{L}$ hydrogen production occurred depending on microaerobic condition or anaerobic in $1 / 3$ time of

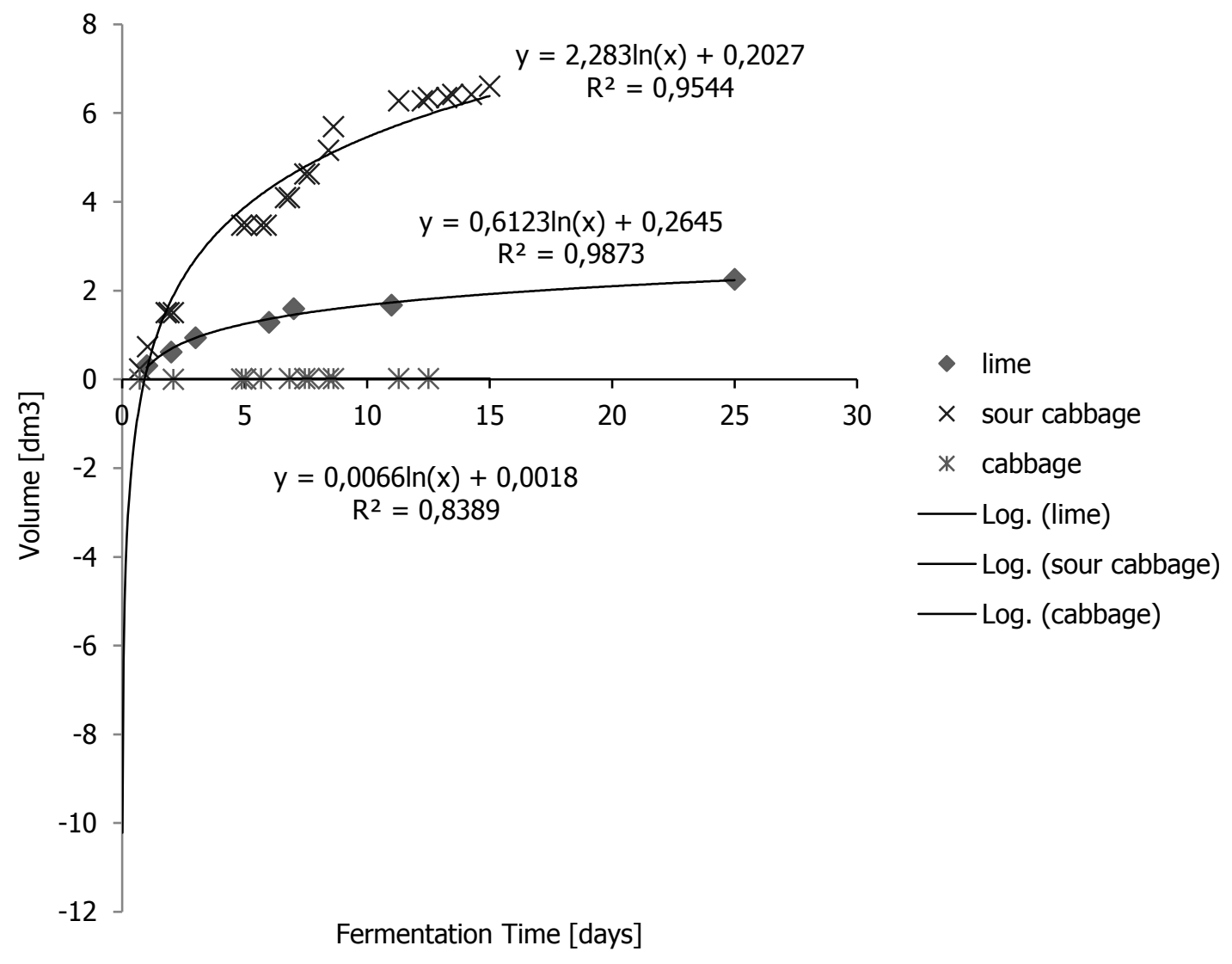

Figure 3 Time evolution of cumulative hydrogen production of lime (blue rhombi), sour cabbage (violet crosses), cabbage (blue-light asterisk) 
process 3 or 1 day before methane peak day. Methane peak days in case of key-lime wastes occurred in the last day of fermentation time while in case of raw cabbage in $1 / 3$ of fermentation process and in sour cabbage almost $1 / 2$ of fermentation time. The key-lime waste are worse methane source than sour cabbage 2.5 times but better than raw cabbage. It can be discerned that lime key is more efficient methane source than cabbage but worse than sour cabbage. In case of cabbage from VSS $10 \mathrm{~g} / \mathrm{L}$ the methane production is 357 times weaker and hydrogen production 16.7 than from sour cabbage.

The results of substrate with raw inoculum can be much worse but such an experiment can allow to choose proper material for dark fermentation using inoculum pretreatment. Key lime and raw cabbage waste are weak source of hydrogen in compare to other substrates (volume of hydrogen in biogas are negligible). Key lime is 149 times worse hydrogen source via dark fermentation than raw cabbage. Despite of presence of citric acid that pKa is lower than lactic acid, key lime is much worse source of hydrogen both from cabbage and sour cabbage.

Characteristics show that sour cabbage possess the lowest total solid value from the substrates and then key lime and lowest is raw cabbage. Therefore, availability of substrate for methane or hydrogen production depends not only from $\mathrm{pH}, \mathrm{pKa}$, but also relevant dependent is not too high total solid parameter. The methane production is produced in lower level in key lime than in raw cabbage. Difference of key-lime from cabbage and sour cabbage is that biogas from one portion of substrates can be produced longer. Comparing sour cabbage with raw cabbage results can be discerned dependence of proper substrate pretreatment to efficiency of process dark fermentation and anaerobic digestion. Neutral conditions of investigation allowed to assess availability of the substrates for hydrogen production and methane without special pretreatment or other unit operation that increases costs of the research. The initial conditions (neutral $\mathrm{pH}$ ) are usually more suitable for methane production (Rabii et al., 2019) than hydrogen production. However, dark fermentation for some substrates in nonacidic $\mathrm{pH}$ can give high volumes of hydrogen like Li et al. (2018) Klebsiella sp. WL1316, could effectively produce a high yield of hydrogen by using cotton stalk hydrolysate as substrate. The optimum fermentation conditions for hydrogen production were determined as follows: an initial sugar concentration of $40 \mathrm{~g} / \mathrm{L}$, a fermentation temperature of $37^{\circ} \mathrm{C}$ and an initial $\mathrm{pH}$ value of 8.0.

The scaled-up fermentation process was conducted in a 5-L fermenter using these parameters. Higher productivities with maximum daily hydrogen production of $937.0 \pm 41.0 \mathrm{~mL} \mathrm{~L}-1$ day-1, cumulative hydrogen production of $2908.5 \pm 47.4 \mathrm{~mL} \mathrm{~L}-1$, viable cell count of ( $20.2 \pm 0.6$ or gangrene that is 'unwanted'(for man) dark fermentation in our body (Sołowski et al., 2019) but the cases of key-lime or cabbage are not exclusion from the rules of efficient hydrogen production (Kozłowski et al., 2019).

\section{CONCLUSIONS}

Key lime is a potential source of methane production, worse 2.5 times than sour cabbage but 32 times more than raw cabbage. Key lime produces biogas 9 days longer than cabbage and sour cabbage for the same concentration of substrate. Fermentation of cabbage by lactic acid to form sour cabbage (sauerkraut) improves much their abilities for methane production 357 times and hydrogen production 16.7 times. Contrary to the subjects of research sour cabbage is both a potential source of methane production from anaerobic digestion and source of hydrogen by dark. Raw cabbage and keylime are not good source of hydrogen with untreated sludge and does not seem to be a good substrate of dark fermentation with treated (stressed) sludge. Keylime properties shows that lower $\mathrm{pH}$ of substrates and pKa is not the most relevant reason of quite efficient hydrogen and methane production in sour cabbage. The relevant parameter for design an anaerobic digestion process is total solid with volatile suspended solids. Key lime wastes and raw cabbage are quite efficient source of methane therefore can be considered as component or only substrate in designing of biogas plants.

The phenomena needs further research and other materials will be selected for checking their methane and hydrogen production.

\section{ACKNOWLEDGEMENTS}

Special thanks for RENK Pomeranian Agri-food Wholesale Center S.A for possibility of using their wastes of cabbage, sour cabbage and key limes that allows to make this research. The research was supported by the National Centre for Research and Development in Poland, under project no. BIOSTRATEG 3/344128/12/ NCBR/2017 and Institute of Fluid-Flow Machinery, Polish Accademy of Science in Gdansk (grant number FBW-44 - Solowski).

\section{CONFLICT OF INTEREST}

There was no conflict interest of the article publication. 


\section{REFERENCES}

Braguglia, C. M., Gallipoli, A., \& Gianico, A. (2018). Anaerobic bioconversion of food waste into energy: a critical review. Bioresource Technology, 248(January), 37-56. http://doi.org/10.1016/j.biortech.2017.06.145

Cheng, J., Yue, L., Ding, L., Li, Y. Y., Ye, Q., Zhou, J., ... Lin, R. (2019). Improving fermentative hydrogen and methane production from an algal bloom through hydrothermal/ steam acid pretreatment. International Journal of Hydrogen Energy, 44(12), 5812-5820. http://doi. org/10.1016/j.ijhydene.2019.01.046

Chi, C. H., Chen, K. W., Huang, J. J., Chuang, Y. C., \& Wu, M. H. (1995). Gas composition in Clostridium septicum gas gangrene. Journal of the Formosan Medical Association = Taiwan Yi Zhi, 94(12), 757-759.

Chojnacka, A., Szczęsny, P., Błaszczyk, M. K., Zielenkiewicz, U., Detman, A., Salamon, A., \& Sikora, A. (2015). Noteworthy facts about a methane-producing microbial community processing acidic effluent from sugar beet molasses fermentation. PLOS ONE, 10(5). http://doi. org/10.1371/journal.pone.0128008

Detman, A., Mielecki, D., Pleśniak, Ł., Bucha, M., Janiga, M., Matyasik, I., Sikora, A. (2018). Methane-yielding microbial communities processing lactate-rich substrates: A piece of the anaerobic digestion puzzle. Biotechnology for Biofuels, 11(1). http://doi.org/10.1186/s13068-0181106-z

Grosser, A., \& Neczaj, E. (2016). Enhancement of biogas production from sewage sludge by addition of grease trap sludge. Energy Conversion and Management, 125, 301308. http://doi.org/10.1016/j.enconman.2016.05.089

Hawkes, F. R., Dinsdale, R., Hawkes, D. L., \& Hussy, I. (2002). Sustainable fermentative hydrogen production: Challenges for process optimisation. International Journal of Hydrogen Energy, 27(11-12), 1339-1347. http://doi.org/10.1016/S0360-3199(02)00090-3

Jaiswal, A. K., Gupta, S., \& Abu-Ghannam, N. (2012). Optimisation of lactic acid fermentation of York cabbage for the development of potential probiotic products. International Journal of Food Science \& Technology, 47(8), 1605-1612. http://doi.org/10.1111/j.13652621.2012.03010.x

Kozłowski, K., Lewicki, A., Malińska, K., \& Wei, Q. (2019). Current State, Challenges and Perspectives of Biological Production of Hydrogen in Dark Fermentation Process in Poland, 20(2), 146-160. http://doi. org/10.12911/22998993/97270

Kurtz, J., Sprik, S., \& Bradley, T. H. (2019). Review of transportation hydrogen infrastructure performance and reliability. International Journal of Hydrogen Energy, 44(23), 12010-12023. http://doi.org/10.1016/j. ijhydene.2019.03.027
Lakaniemi, A. M., Koskinen, P. E. P., Nevatalo, L. M., Kaksonen, A. H., \& Puhakka, J. A. (2011). Biogenic hydrogen and methane production from reed canary grass. Biomass and Bioenergy, 35(2), 773-780. http://doi. org/10.1016/j.biombioe.2010.10.032

Lamb, K. E., Dolan, M. D., \& Kennedy, D. F. (2019). Ammonia for hydrogen storage; A review of catalytic ammonia decomposition and hydrogen separation and purification. International Journal of Hydrogen Energy, 44(7), 35803593. http://doi.org/10.1016/j.ijhydene.2018.12.024

Li, Y., Zhang, Q., Deng, L., Liu, Z., Jiang, H., \& Wang, F. (2018). Biohydrogen production from fermentation of cotton stalk hydrolysate by Klebsiella sp. WL1316 newly isolated from wild carp (Cyprinus carpio L.) of the Tarim River basin. Applied Microbiology and Biotechnology, 102(9), 4231-4242. http://doi.org/10.1007/s00253-018-8882-z

Liu, Y., Heying, E., \& Tanumihardjo, S. A. (2012). History, Global Distribution, and Nutritional Importance of Citrus Fruits. Comprehensive Reviews in Food Science and Food Safety, 11(6), 530-545. http://doi.org/10.1111/ j.1541-4337.2012.00201.x

Merzari, F., Langone, M., Andreottola, G., \& Fiori, L. (2019). Methane production from process water of sewage sludge hydrothermal carbonization. A review. Valorising sludge through hydrothermal carbonization. Critical Reviews in Environmental Science and Technology (Vol. 49). Taylor \& Francis. http://doi.org/10.1080/10643389 .2018 .1561104

Michalopoulos, I., Lytras, G. M., Mathioudakis, D., Lytras, C., Goumenos, A., Zacharopoulos, I., ... Lyberatos, G. (2019). Hydrogen and Methane Production from Food Residue Biomass Product (FORBI). Waste and Biomass Valorization, $O(0)$, 0. http://doi.org/10.1007/s12649018-00550-4

Muñoz-Páez, K. M., Alvarado-Michi, E. L., Buitrón, G., \& Valdez-Vazquez, I. (2018). Distinct effects of furfural, hydroxymethylfurfural and its mixtures on dark fermentation hydrogen production and microbial structure of a mixed culture. International Journal of Hydrogen Energy, 1-9. http://doi.org/10.1016/j. ijhydene.2018.04.139

Noblecourt, A., Christophe, G., Larroche, C., \& Fontanille, P. (2018). Hydrogen production by dark fermentation from pre-fermented depackaging food wastes. Bioresource Technology, 247(July 2017), 864-870. http://doi. org/10.1016/j.biortech.2017.09.199

Pagliaccia, P., Gallipoli, A., Gianico, A., Montecchio, D., \& Braguglia, C. M. (2016). Single stage anaerobic bioconversion of food waste in mono and co-digestion with olive husks: Impact of thermal pretreatment on hydrogen and methane production. International Journal of Hydrogen Energy, 41(2), 905-915. http://doi. org/10.1016/j.ijhydene.2015.10.061 
Parra, D., Valverde, L., Pino, F. J., \& Patel, M. K. (2019). A review on the role, cost and value of hydrogen energy systems for deep decarbonisation. Renewable and Sustainable Energy Reviews, 101(July 2018), 279-294. http://doi.org/10.1016/j.rser.2018.11.010

PETÄJÄ, E., MYLLYNIEMI, P., \& PETÄJÄ, P. (2008). Use of inoculated lactic acid bacteria in fermenting sour cabbage. Agricultural and Food Science, 9(1), 37-48. http://doi.org/10.23986/afsci.5651

Pradhan, N., d'Ippolito, G., Dipasquale, L., Esposito, G., Panico, A., Lens, P. N. L., \& Fontana, A. (2019). Simultaneous synthesis of lactic acid and hydrogen from sugars via capnophilic lactic fermentation by Thermotoga neapolitana of capnolactica. Biomass and Bioenergy, 125(March), 17-22. http://doi.org/10.1016/j. biombioe.2019.04.007

Rabii, A., Aldin, S., Dahman, Y., \& Elbeshbishy, E. (2019). A Review on Anaerobic Co-Digestion with a Focus on the Microbial Populations and the Effect of Multi-Stage Digester Configuration. Energies, 12(6), 1106. http:// doi.org/10.3390/en12061106

Sharma, K. (2019). Carbohydrate-to-hydrogen production technologies: A mini-review. Renewable and Sustainable Energy Reviews, 105(May 2018), 138-143. http://doi. org/10.1016/j.rser.2019.01.054

Sołowski, G. (2018). Biohydrogen Production - Sources and Methods: A Review. International Journal of Bioprocessing and Biotechniques, 2018(01), 1-22. http://doi.org/10.20911/IJBBT-101.

Sołowski, G., Hrycak, B., Czylkowski, D., Cenian, A., \& Konkol, I. (2018). Hydrogen and methane production under conditions of dark fermentation process with low oxygen concentration. In T. Sabu (Ed.), Proceedings of the International Conference on Reuse and Recycling (ICRM 2018), Kottayam, Kerala, India (1st ed.). Kottayam.
Sołowski, G., Hrycak, B., Czylkowski, D., Cenian, A., \& Pastuszak, K. (2018). Oxygen sensitivity of hydrogenesis ' and methanogenesis'. In Pikoń Krzysztof (Ed.), Contenporary Problems of Power Engineering and Environmental Protection 2017 (1st ed., pp. 157-159). Gliwice: Department of Technologies and Installations for Waste Management. http://doi.org/http://cleanalternative.eu/ wp-content/uploads/2018/01/Merged_OSWE_book.pdf

Sołowski, G., Hrycak, B., Czylkowski, D., Konkol, I., Pastuszak, K., \& Cenian, A. (2019). Hydrogen and Methane Production Under Conditions of Dark Fermentation Process with Low Oxygen Concentration. In K. Jibin, N. Kalarikkal, S. Thomas, \& A. Nzihou (Eds.), Re-Use and Recycling of Materials Solid Waste Management and Water Treatment (1st ed., pp. 263-272). Gistrup: River Publisher.

Sołowski, G., Hrycak, B., Czylkowski, D., Pastuszak, K., \& Cenian, A. (2018). Oxygen sensitivity of hydrogenesis ' and methanogenesis '. In K. Pikoń \& C. Lucyna (Eds.), Contemporary Problems of Power Engineering and Environmental Protection 2017 (pp. 157-159). Gliwice: Department of Technologies and Installations for Waste Management Copyright. http://doi.org/http:// cleanalternative.eu/wp-content/uploads/2018/01/ Merged_OSWE_book.pdf

Taheri, E., Amin, M. M., Fatehizadeh, A., Pourzamani, H., Bina, B., \& Spanjers, H. (2018). Biohydrogen production under hyper salinity stress by an anaerobic sequencing batch reactor with mixed culture. Journal of Environmental Health Science and Engineering, 16(2), 159-170. http:// doi.org/10.1007/s40201-018-0304-8 